\title{
Tissue expression of two $\alpha$-amylase genes in the Pacific oyster Crassostrea gigas. Effects of two different food rations
}

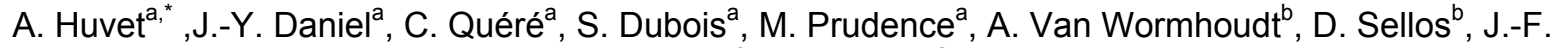 \\ Samain $^{a}$ and J. Moal ${ }^{\mathrm{a}}$
}

a Unité Mixte de Recherche Physiologie et Ecophysiologie des Mollusques Marins, Ifremer, Centre de Brest, B.P. 70, 29280 Plouzané, France

b Station de Biologie Marine du Muséum National d'Histoire Naturelle, BP225, 29900 Concarneau, France

*: Corresponding author : Tel.: +33-2-98-22-46-93; fax: +33-2-98-22-46-53

\begin{abstract}
:
A semi-quantitative reverse transcription-polymerase chain reaction (RT-PCR) assay was developed to estimate tissue-specific expression of two amylase genes in five different tissues of the Pacific oyster Crassostrea gigas and the experimental effects of food level on the cellular, enzymatic and gene expression changes of the digestive gland. Results indicated that both genes were transcribed at different levels depending on tissue type. A strong preferential expression of both amylase genes was observed in the digestive gland leading to high amylase activities, in accordance with the digestive function of this organ. Traces of gene expression and activity were observed in other analysed tissues. These appeared higher in labial palps than in other non-digestive tissues. After 4 weeks of feeding two groups of oysters on either a high or low food level, cellular growth of the digestive gland $(+56 \%)$ and increase in the total activity of amylase enzymes and in specific amylase activity $(+50 \%)$ were observed under high food conditions compared to low food conditions. A significant increase $(+18 \%)$ in the expression of gene A was observed in the digestive gland of oysters fed the high ration compared to that of oysters fed on the low food level whereas no changes in the expression of gene $B$ were observed. Gene A was expressed at a higher level than gene B in all tissues and at all conditions. A role of the amylase gene $A$ in digestive processes and changes in its expression according to food availability is demonstrated in this study. The functional role of the a-amylase B gene remains to be elucidated.
\end{abstract}

Author keywords: $\alpha$-Amylase; Digestive enzyme activity; Food regulation; Gene expression; Oyster 


\section{Introduction}

Knowledge of feeding strategies and adaptive digestive capacities displayed by bivalves under different food conditions and their effects on phenotypic traits, such as growth and survival, is of major interest in aquaculture. Since its introduction in France in 1972 the Pacific cupped oyster Crassostrea gigas has become successfully established as a major aquaculture species. However, increased aquaculture of this species has been correlated with a decrease in productivity due to competition for limited food supplies at grow-out sites (i.e. Héral et al., 1986). Furthermore, overstocking increases risk of diseases (Deslous-Paoli et al., 1982) and over the last 20 years increasing mortalities have been observed at French oyster farms (Goulletquer et al., 1998). Among the proposed actions to address this problem of food limitation for oyster aquaculture in France is to better understanding the physiological and environmental factors that determine optimal food conversion efficiencies for oysters (Goulletquer et al., 1999).

Until recently, the basic knowledge of key physiological processes of digestion, and more broadly in growth and development, remains poorly understood in marine bivalves. To date, feeding rates (Bayne et al., 1999), assimilation and aneuploidy (S. Bougrier and P. Boudry, Pers. Comm.) are the main parameters explaining in situ growth variability of $\underline{\mathrm{C} \text {. gigas. In }}$ mussels and scallops, good relationships between assimilation rates and digestive processes has been described (Bayne, 1976; Samain et al., 1991). In cockles, digestive enzymes activities were identified as a physiological parameter affecting digestive capacity (Ibarrola et al., 1998a). Control of digestive enzyme activities may be, therefore, important in maximizing absorption efficiencies and food conversion efficiencies.

Among digestive enzymes in bivalves, two main enzymes, laminarinase and $\alpha$-amylase, have a carbohydrase function and catalyse the hydrolysis of internal $(\beta-1,3)$ and $(\alpha-1,4)$ glucosidic bonds in laminarin and in starch of related poly and oligosaccharides, respectively. We 
selected $\alpha$-amylase ( $\alpha-1,4$ glucan-4-glucanohydrolase) as a model enzyme because this enzyme is widely distributed in most species (animals, plants, bacteria, fungi; Svensson, 1988) and biochemical and molecular data (such as gene structure) are available. This is also due to the high activities of amylases present in the digestive tracts of Pacific oysters (Moal et al., 2000).

In Pacific oysters, one amylase cDNA was fully sequenced and relationships between amylase activity and total amylase mRNA level (estimated by dot hybridization) were observed depending on daily changes in food availabilities (Moal et al., 2000). A possible

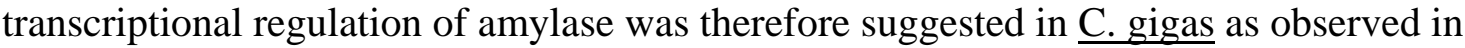
mammalian species (Giorgi et al., 1984; Wicker et al., 1984). In those species, this enzyme is mostly encoded by two genes corresponding to salivary and pancreatic forms (Darnis et al., 1999). Specific promoters were identified and variable levels of expression according to organ were reported in mammals depending on which promoters operated due to tissue specific signals (Hagenbuchle et al., 1985; Schibler and Sierra, 1987). In Pacific oysters, two different genes, coding for two amylase messengers, were recently identified and their molecular structure characterised (Sellos et al., 2003). Their intron-exon structure is similarly organized with eight exons and seven introns. Promoter regions were identified for both $\alpha$-amylase genes but only the gene B revealed putative regulatory elements similar to those found in Drosophila. Reported variations of nucleotides along the exons of the two genes led to a mean value of $10.4 \%$ of variation of amino acids between the two deduced protein sequences. To date, screenings of cDNA libraries have not allowed characterization of the cDNA of gene B

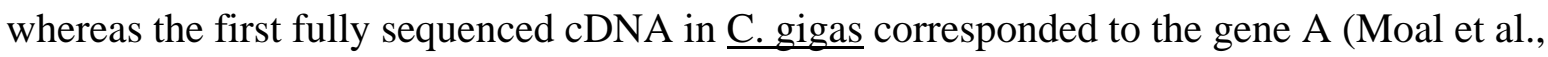
2000).

A better knowledge of the regulation of expression of each amylase gene is required to understand the relationships between enzymatic properties and absorption processes. In this 
paper, we report the semi-quantitative assay of the tissue-specific expression of the two amylase genes and the assay of specific enzymatic activities in five different tissues of the

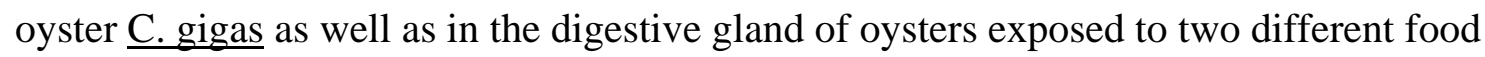
levels. The experimental effects of food level on cellular and molecular processes of the digestive gland are discussed. 


\section{Material and Methods}

\subsection{Biological material}

Two groups of three-year-old Pacific cupped oysters Crassostrea gigas $($ mean total weight $=$ $55 \pm 5$ g) were collected from the bay of Marennes-Oléron, the main oyster farming area in France, in December and January, respectively. The first group of 30 oysters was immediately used for the dissection of five tissues (digestive gland, muscle, mantle, gills and labial palps) that were then stored in liquid nitrogen for total RNA extraction (T0). Oysters of the second group underwent an acclimation period of 8 days at $17.0 \pm 1.0^{\circ} \mathrm{C}$ in seawater filtered at 20 $\mu \mathrm{m}$ (sand filter) before being exposed to two different food levels.

\subsection{Experimental design}

Oysters were placed in two experimental raceways (150l) in seawater filtered to $20 \mu \mathrm{m}$ (sand filter) at $17 \pm 1.0{ }^{\circ} \mathrm{C}$ and fed either a low level of food $\left(0.06 \times 10^{9}\right.$ cells of $\underline{\text { T-Isochrysis }}$ galbana day ${ }^{-1}$ oyster $^{-1}$ and $0.06 \times 10^{9}$ cells of Chaetoceros calcitrans day $^{-1}$ oyster $^{-1}$, equal to $0.3 \%$ dry weight algae/dry weight oyster) or a high level of food $\left(1.2 \times 10^{9}\right.$ cells of $\underline{\mathrm{T}}$ $\underline{\text { Isochrysis galbana }}$ day $^{-1}$ oyster $^{-1}$ and $1.2 \times 10^{9}$ cells of $\underline{\text { Chaetoceros calcitrans }}$ day $^{-1}$ oyster $^{-1}$, equal to $6 \%$ dry weight algae/dry weight oyster). After 4 weeks, 45 oysters were collected from each food level treatment and their digestive glands immediately dissected, weighed and stored in liquid nitrogen for total RNA extraction and enzyme activity (T1).

\subsection{Nucleic acid extractions}

The extraction of total RNA from the 5 tissues collected at T0 and the digestive gland collected at T1 was performed using the "Mini extraction kit RNA/DNA" from QIAGEN. For 
each sample, RNA concentrations were measured at $260 \mathrm{~nm}$ using the conversion factor $1 \mathrm{OD}$ $=40 \mu \mathrm{g} / \mathrm{ml}$ RNA.

\subsection{Reverse transcription - Polymerase Chain Reaction (RT-PCR)}

The level of amylase mRNA was investigated using an RT-PCR assay. Samples of polyadenylated RNA were reverse-transcribed from $1 \mu \mathrm{g}$ of total RNAs denatured $10 \mathrm{~min}$ at $70^{\circ} \mathrm{C}$. Reactions were carried out in a total volume of $25 \mu \mathrm{l}$ and the concentrations of the reaction components were as follows: $1 \mathrm{X}$ M-MLV Reverse Transcriptase buffer, $0.2 \mathrm{mM}$ dNTPs, 4 mM DTT, $0.5 \mu$ g oligo(dT) primer, 25 U ribonuclease inhibitor and $50 \mathrm{U}$ M-MLV Reverse Transcriptase. Reverse Transcription was realised $10 \mathrm{~min}$ at $25^{\circ} \mathrm{C}, 20 \mathrm{~min}$ at $42^{\circ} \mathrm{C}$ and 5 min at $94^{\circ} \mathrm{C}$ and then immediately stopped on ice.

Primers of each amylase gene were designed to specifically amplify by PCR the cDNA of gene A (Ha forward: AGC ACG GGA GAC GGC AAT and aH reverse: TGA GGG GGG CCC TGC CAA T) and of gene B (Hb2 forward: GTA GCA CAG GAG ATG GC and bH reverse: TGA GGG GGT CCC ATC CAG C) (Sellos et al., 2003). Amplification of actin cDNA was performed in order to confirm the steady-state level of expression of a housekeeping gene allowing an internal control for amylase gene expression (Douglas et al.,

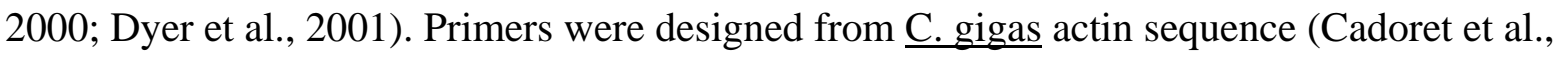
1999) that spanned intron-exon boundaries avoiding bias from trace amounts of DNA in the RNA extracts and produced a fragment of similar size to amylase amplified fragments (Actin Forward primer: GAC GCC CCA GAC ATC AGG GT; Actin reverse primer: GTG ATG ACC TGA CCG TCG GG). The PCR amplifications of actin messenger and amylase messengers were performed under the same procedure. These were carried out in a total volume of $20 \mu \mathrm{l}$ using $3 \mu \mathrm{l}$ of cDNA template. The concentrations of the reaction components were as follows: $1 \mathrm{X}$ Taq buffer, $0.25 \mathrm{mM}$ dNTPs, $1.25 \mu \mathrm{M}$ each primer, $1.5 \mathrm{mM} \mathrm{MgCl}_{2}$ and 
0.5 U Taq polymerase. Amplification was performed using 30 cycles of 30 sec denaturation at $94^{\circ} \mathrm{C}, 1 \mathrm{~min}$ annealing at $62^{\circ} \mathrm{C}$ and $2 \min 30 \mathrm{sec}$ extension at $72^{\circ} \mathrm{C}$. Amylase and actin PCR products are 650 and 610 bp length for cDNA. Controls were performed without reverse transcriptase. Furthermore, putative contaminating genomic DNA is easily detectable because amylase PCR products of DNA are 1200 bp length due to the presence of two introns between specific primers for both amylase genes (Sellos et al., 2003).

The amplified fragments by PCR were separated by electrophoresis on $1 \%$ agarose gels with TAE buffer in $1 \mathrm{X}$ TAE buffer (Tris-acetic acid-EDTA), followed by staining with ethidium bromide. The amount of each PCR product was quantified using the Multi-analyst software (Biorad, CA) with the background signal removed. The obtained value is the spot intensity expressed as mean count per pixel and multiplied by the spot surface. The amount of amylase transcript for each gene was calculated relative to the amount of actin transcript.

\subsection{Enzymatic analysis}

These assays were carried out for all sampled tissues (T0) and for the digestive gland sampled at the final step (T1) in the two food level treatments. All these samples were ground in distilled water with $0.02 \mathrm{M} \mathrm{CaCl}_{2}$ before analysis. Amylase activity was then assayed by determination of starch hydrolysis according to the iodine reaction (Samain et al., 1977) except that the conditions were adapted to bivalve amylases as described in Le Moine et al. (1997). One unit of alpha-amylase was defined as the amount of enzyme that degrades 1 $\mathrm{mg} / \mathrm{min}$ starch at $45^{\circ} \mathrm{C}$. Total proteins were determined according to the method of Lowry et al. (1951).

\subsection{Data analysis}


Comparisons of levels of amylase mRNA between the five different tissues $(\mathrm{T} 0, \mathrm{n}=30)$ and tests of the effects of food availability $(\mathrm{T} 1, \mathrm{n}=45)$ on mean fresh weight of digestive gland, mRNA levels and amylase activities, were performed by analysis of variance under the general model procedure using SYSTAT 9.0 by SPCC Inc. Multiple comparisons were made using the least significant difference (LSD) pairwise multiple comparison test using the same software. 


\section{Results}

\subsection{Development of a semi-quantitative RT-PCR assay}

Although the three genes were separately amplified, preliminary RT-PCR assays were performed to optimize protocol conditions to be able to analyse the three genes in the exponential range of amplification in a single run of PCR. Five different PCR conditions (i.e. 20, 25, 30, 35 and 40 rounds) with different cDNA template quantities were tested. Results obtained from digestive gland were in the exponential range of amplification with 30 PCR cycles starting with different quantities of cDNA template for each gene (Fig 1): $3 \mu \mathrm{l}$ of cDNA template was used for the PCR amplification of the gene B product whereas the same volume was diluted by one twentieth and fortieth for gene A and actin gene, respectively. In all the other tissues, of actin gene expression similarly indicated the need for 30 PCR cycles to ensure exponential amplification under the same conditions used for the digestive gland.

\subsection{Tissue expression}

Analysis of amylase gene expression based on RT-PCR showed that, relative to actin gene expression, both genes were transcribed at different levels depending on the tissues (Fig 2). The main expression of the two genes was in digestive gland, however, trace mRNA were observed for each amylase genes in all tissues. Two distinct expression groups for the gene A were statistically evident: (1) digestive gland and (2) palps, gills, mantle and muscle (Table 1). Indeed, the expression in palps of gene A in relation to actin gene expression $(0.0012 \pm$ 0.0007) was around 200 times less than in digestive gland $(0.246 \pm 0.036)$ whereas in other tissues this difference was up to 800 times less (from 0.0003 to 0.00007 in mantle and muscle, respectively). For the gene $\mathrm{B}$, the two statistically distinct expression groups were the same as those observed for the expression of gene A (Table 1): expression in relation to actin gene 
expression in gills, palps and mantle ranged from 0.0001 to 0.0004 which was 10 to 30 times less than in digestive gland $(0.0032 \pm 0.001)$ (Fig 2).

A highly significant difference was revealed between expression of A and B amylase genes in relation to actin gene expression in the digestive gland (mean values $=0.246$ and 0.0032 , respectively) which was around 70 times greater for the expression of gene A $(P<0.001$; Table 2). Furthermore, a slight significant difference was noticed in the labial palps where expression of gene A was greater $(P=0.03$; Table 2$)$ whereas no significant differences $(\mathrm{P}>$ 0.05) were observed between the expression of both amylase genes in relation to actin gene expression in gills, mantle and muscle (Table 2).

The main specific amylase activity was located in the digestive gland (mean $=0.425 \mathrm{UI} / \mathrm{mg}$ of proteins) but traces were observed in the other tissues ranging from 0.003 to 0.06 in gills and labial palps, respectively. Three distinct groups for specific amylase activity were therefore revealed statistically: (1) digestive gland, (2) palps, gills, mantle and (3) gills, mantle, muscle (Table 1).

\subsection{Effects of food level}

At the end of the period of exposure to the two food levels, digestive glands were dissected from 45 oysters in each treatment and weighed. The mean fresh weight of the digestive gland was $56 \%$ higher in oysters from the high food level $(0.61 \pm 0.15 \mathrm{mg})$ compared with that of oysters from the low food level $(0.39 \pm 0.12 \mathrm{mg})(P<0.001$; Table 3$)$. Both were significantly higher $(\mathrm{F}=62.8, P<0.001)$ than the initial mean fresh weight of the digestive gland (0.31 $\pm 0.11 \mathrm{mg})$ estimated at the beginning of the experiment.

A significant difference ( $+50 \%, P<0.001$; Table 3 ) in amylase specific activities was observed for oysters exposed to the two food conditions, with values ranging from $0.36 \pm 0.18$ to $0.54 \pm 0.13 \mathrm{UI} / \mathrm{mg}$ of protein in the low and high food conditions, respectively. 
Similarly, a significant increase $(+18 \%)$ in the expression of gene A in relation to actin gene expression was observed under high food conditions compared to low food conditions $(P=$ 0.038; Table 3) with mean values ranging from 0.245 to 0.288 in low and high levels, respectively. In contrast, no significant difference in the expression of gene B was observed between oysters sampled from the two food conditions (mean values $=0.0044$ and 0.0049 with low and high food levels, respectively; $P=0.41$; Table 3). As already noticed in tissue expression analysis, a significantly higher expression of gene A compared with gene B (55 and 58 times in low and high food levels, respectively) was observed in the digestive gland $(P<0.001$; Table 2). 


\section{Discussion}

\subsection{Development of a semi-quantitative RT-PCR assay}

The accurate and sensitive estimation of amylase gene expression required a semi-quantitative RT-PCR assay. First, using actin gene expression as an internal control takes into account variation between samples in RNA extractions and RT yields. Second, during PCR protocols, quantitative results are only obtained in the exponential range of amplification (O’Connell et al., 1999; Raeymakers, 1999). Trials were performed to ensure that PCR assays were conducted using the exponential range and a single run was used with an identical number of PCR cycles for the three genes. Good results were obtained for 30 PCR cycles for gene B directly using the RT product. Dilutions of RT product (1/20, 1/40) were necessary for amylase A gene and actin gene respectively to be within the exponential phase with 30 cycles. These assays showed that large differences existed between amylase gene (A and B) and actin gene expression.

\subsection{Tissue expression}

Both amylase genes were transcribed at different apparent rates depending on tissue. A strong preferential expression of both genes and enzymatic activity was observed in the digestive gland. This result is in accordance with the digestive function of this organ in $\underline{\mathrm{C} \text {. gigas which }}$ carries out both extra and intracellular digestion (Morton, 1983; Henry et al., 1993).

Expression of amylase gene A appeared to be significantly greater compared with that of gene B (70 times higher in digestive gland) which suggests a more important role in oyster digestive processes than gene $\mathrm{B}$. This could explain characterization in a previous study of a single cDNA, corresponding to the product of gene A, from a cDNA digestive gland library (Moal et al., 2000). 
For both amylase genes, very small amounts of mRNA were observed in other tissues with no digestive functions: gills, mantle, muscle and labial palps. Weak enzymatic activities were also observed in these tissues in the same order as those observed for mRNA levels: palps, muscle, mantle and gills in descending order of activities. A low, steady-state level of expression of both amylase genes could be hypothesised in these non-digestive tissues in C. gigas but the functional role of the amylase enzymes is unclear. Amylase activity and expression appeared higher in the labial palps than in the non-digestive tissues. Labial palps (paired triangular flaps located on each side of the mouth) are implicated in acceptance or rejection of particles for ingestion by oysters (Morton, 1983) and might be the location of secretion of pre-digestive enzymes, similar in function to the salivary glands of mammals. In those organs, specific regulations due to promoting sequences and tissue signals result in a variable expression profile (Hagenbuchle et al., 1985; Maniatis et al., 1987; Gumucio et al., 1988). Transcription of amylase gene 1 (corresponding to the human salivary form) was observed in the parotid gland and in the liver whereas expression of the gene 2 (corresponding to the human pancreatic form) was limited to the pancreas (Darlington et al., 1986). In each organ, variable levels of expression of the $\alpha$-amylase gene 1 were reported due to the alternative or simultaneous use of two different promoters (Schibler et al., 1983; Shaw et al., 1985; Schibler and Sierra, 1987). In oysters, promoter regions have been identified for the $\alpha$ amylase genes but a specific organisation and some putative regulatory elements were only observed for the gene B (Sellos et al., 2003).

The hypothesis of a further physiological role of amylase, in addition to their strict digestive function, is supported by reports of amylase activities in mammals. Indeed, liver-specific amylases displayed a strong affinity to glycogen in rats and were found to be capable of glycogen hydrolysis and glucose formation (Koyama et al., 2001). Furthermore, $\alpha$-amylase has been reported to be capable of hydrolysis of oyster glycogen (Matsui et al., 1996). Such a 
biochemical function (i.e. role of glycogenase) might be hypothesised in oysters considering that amylase activity and amylase transcripts were found to be higher in labial palps, which is a glycogen storage tissue in oysters (Heude-Berthelin, 2000), than in other non-digestive tissues (gills, mantle, muscle). In these latter tissues, traces might be implicated in low level glycogen storage described for most of oyster tissues (Berthelin et al., 2000).

\subsection{Feeding responses of the digestive gland}

In the present paper, the effects of food availability were measured in the digestive gland in terms of cellular, enzymatic and molecular responses to advance understanding of digestive regulation. First, we observed a significant increase (+ 56\%) in the mean wet weight of digestive glands in four weeks, depending on food availability. Such a physiological response is often observed in bivalves, for example the increase in size of digestive tubules in cockles resulting in a volume increase of the whole digestive organ (Ibarrola et al., 2000). The increase in size of the digestive structures was linked to synthesis of digestive enzymes, leading to an increase in their total activity (Ibarrola et al., 1996, 1998b).

A significant increase ( $+18 \%)$ of translatable mRNA for gene A was observed with a correlative increase (+50\%) in specific amylase activity when food availability increased whereas no significant changes were observed for gene B. Several factors may influence the increase of translatable mRNA including the rate of gene transcription, the efficiency of processing of the primary transcript and the stability of the mature cytoplasmic mRNA. In mammalian pancreatic acinar cells, differences in amylase protein concentration were thought to be mostly related directly to amylase gene transcription (Logsdon et al., 1987). Other researchers have reported increases in levels of amylase protein and activity in the presence of decreased mRNA (Swanson et al., 2000) suggesting regulatory factors that are different from the rate of gene transcription. Our data demonstrate that amylase concentrations could, at least 
partially, be linked to an increase in translatable mRNA for the amylase A form in response to variation in food availability. However, the magnitude of mRNA differences due to food availability and between tissues was not in agreement with differences in specific activities, suggesting different levels of regulation and/or desynchronized variation in amylase activity and in total amylase mRNA levels as previously reported for $\underline{\text { C. gigas }}$ exposed to daily changes in food availabilities (Moal et al., 2000).

We demonstrated the ability of the amylase gene A to be regulated at the transcriptional level when food varied quantitatively whereas the gene B was not regulated under these conditions. Hence, food availability constitutes an external regulatory factor for amylase A gene in the Pacific oyster $\underline{\text { C. gigas. }}$ Other external factors should be tested for their potential regulatory effects, such as food quality. In $\underline{\text { C. gigas, }}$ significant changes in clearance rates and net energy balance have already been reported, depending on the species of diatom used as a food source for adult oysters (Barillé et al., 2003). Diet quality is likely to have an effect on amylase activity because different classes of algal species vary in carbohydrate and starch content (Moal et al., 1987). For example, regulation in amylase activity and active cytoplasmic mRNAs was reported at the cellular and molecular levels due to changes in the carbohydrate content of diets in rats (Wicker et al., 1984). Amylase isozymes were also reported to vary in

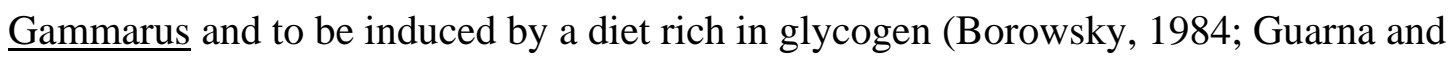
Borowsky, 1995). Adaptation of digestive enzymes, such as amylase, was also observed in shrimp, depending on casein and protein sources in diets (Le Moullac et al., 1997). These examples emphasize the potential effects of food quality on regulation processes of amylase A and $\mathrm{B}$ genes in $\underline{\mathrm{C} \text {. gigas. }}$

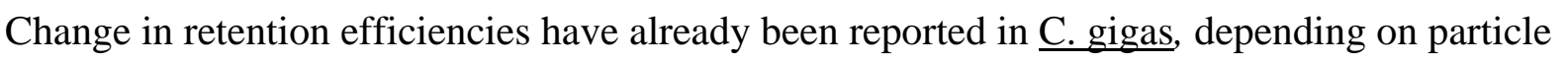

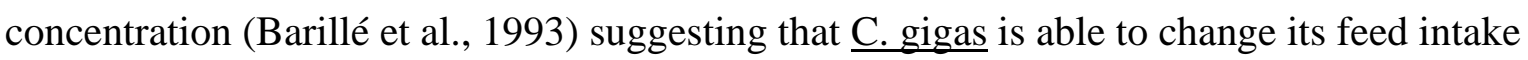
depending on food availability and thereafter enhance digestion processes. Therefore, 
quantifying the ingestion of the animal coupled with biochemical and molecular assays will be necessary to estimate all the putative levels of regulation due to variations in food quality and quantity. 


\section{Conclusion}

The present paper shows the main role of the amylase gene A which is associated with oyster digestive processes and its expression is mainly localised in the digestive gland where it is regulated according to variation in food quantity at the transcription level. The amylase gene $\mathrm{B}$ is also mainly expressed in the digestive gland, at a lower level than gene $\mathrm{A}$, but its expression does not respond to variation in food quantity. The functional role of the $\alpha$ amylase B gene and its catalytic properties remain to be elucidated.

Increase in food quantity also resulted in cellular growth of the digestive gland leading to an increase of total amylase activity with probably an increase of cell number. Moreover, the specific activity of amylase increased which might be linked to the observed increase of translatable mRNA of gene A. In total, there was a 105\% difference in the total amylase activity of the digestive gland of oysters fed on the two different food levels, while there was only a $18 \%$ difference in mRNA, suggesting different modes of amylase regulation.

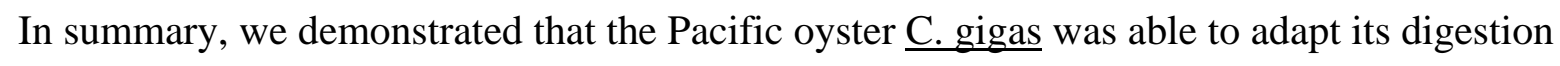
according to food availability in the environment. Such an adaptative response of digestive enzymes will probably affect digestion and absorption efficiencies for the corresponding substrate. Studying the variability of such a response at the level of an individual would be of great interest in the explanation of differences in growth rates among individuals. 


\section{Acknowledgements}

The authors are grateful to J.C. Cochard for his support during the course of this work. We also acknowledge Chris Langdon (Oregon State University) for helpful comments on the manuscript and for his help for editing English language. The authors are indebted to all the staff of the Argenton Ifremer hatchery for providing algae.

\section{References}

Barillé, L., Prou, J., Héral, M., Bougrier, S., 1993. No influence of food quality, but rationdependent retention efficiencies in the Japanese oyster Crassostrea gigas. J Exp Mar Biol Ecol 171, 91-106.

Barillé, L., Haure, J., Pales-Espinose, E., Morançais, M., 2003. Finding new diatoms for intensive rearing of the Pacific oyster (Crassostrea gigas): energy budget as a selective tool. Aquaculture, 217, 501-514.

Bayne, B.L., 1976. Marine Mussels, Their Ecology and Physiology. Cambridge University Press, London, pp 494.

Bayne, B.L., Hedgecock, D., McGoldrick, D., Rees, R., 1999. Feeding behaviour and metabolic efficiency contribute to growth heterosis in Pacific oysters Crassostrea gigas (Thunberg). J Exp Mar Biol Ecol 233, 115-130.

Berthelin, C., Kellner, K., Mathieu, M., 2000. Storage metabolism in the Pacific oyster (Crassostrea gigas) in relation to summer mortalities and reproductive cycle (West Coast of France). Comp Biochem Physiol 125B, 359-369.

Borowsky, R., 1984. Environmental control of amylase phenotype in amphipods of the genus Gammarus. Biol Bull 167, 647-657. 
Cadoret, J.P., Debon, R., Cornudella, L., Lardans, V., Morvan, A., Roch, P., Boulo, V., 1999. Transient expression assays with the proximal promoter of a newly characterized actin gene from the oyster Crassostrea gigas. FEBS letters 460, 81-85.

Darlington, G.J., Tsai, C.C., Samuelson, L.C., Gumucio, D.L., Meisler, M.H., 1986. Simultaneous expression of salivary and pancreatic amylase gene in cultured mouse hepatoma cells. Mol Cell Biol 6, 969-975.

Darnis, S., Juge, N., Guo, X.J., Marchis-Mouren, G., Puigserver, A., Chaix, J.C., 1999. Molecular cloning and primary structure analysis of porcine pancreatic $\alpha$-amylase. Biochim Biophys Acta 1430, 281-289.

Deslous-Paoli, J.M., Zanette, Y., Héral, M., Masse, H., Garnier, J., 1982. Amélioration de la forme et de la qualité de l’huître Crassostrea gigas dans les claires de Marennes-Oléron. Revue des Travaux de l’Institut des Pêches Maritimes 45, 181-194.

Douglas, S.E., Mandla, S., Gallant, J.W., 2000. Molecular analysis of the amylase gene and its expression during development in the winter flounder, Pleuronectes americanus. Aquaculture 190, 247-260.

Dyer, A., Soole, K., Matsumoto, G., 2001. Quantitative TaqMan PCR without a real-time thermal cycler: an assay for fish insulin-like growth factor I messenger RNA. Mar Biotech 3, 16-21.

Giorgi, D., Bernard, J.P., Lapointe, R., Dagorn, J.C., 1984. Regulation of amylase messenger RNA concentration in rat pancreas by food content. EMBO Journal 3, 1521-1524.

Goulletquer, P., Soletchnik, P., Le Moine, O., Razet, D., Geairon, P., Faury, N., Taillade, S., 1998. Summer mortality of the cupped oyster Crassostrea gigas in the bay of Marennes Oléron (France). ICES, Lisbon (Portugal) ICES, CM. CC/14, pp 14-20.

Goulletquer, P., Wolowicz, M., Latala, A., Geairon, P., Huvet, A., Boudry, P., 1999. Comparative analysis of oxygen consumption rates between cupped oyster spat of 
Crassostrea gigas of French, Spanish and Taiwanese origins. Aqua Liv Res 12 (4), 271277.

Guarna, M.M., Borowsky, R.L., 1995. Biochemical properties of amylase isozymes from

Gammarus palustris. A comparative study. Comp Biochem Physiol 112B, 619-628.

Gumucio, D.L., Wiebauer, K., Caldwell, R.M., Samuelson, L.C., Meisler, M.H., 1988.

Concerted evolution of human amylase genes. Mol Cell Biol 8, 1197-1205.

Hagenbuchle, O., Schibler, U., Petrucco, S., Van Tuyle, G.C., Wellauer, P.K., 1985.

Expression of mouse Amy-2a alpha-amylase genes is regulated by strong pancreasspecific promoters. J Mol Biol 185, 285-293.

Henry, M., Benlimame, N., Boucaud-Camou, E., Mathieu, M., Donval, A., 1993. The amylase-secreting cells of the stomach of the scallop, Pecten maximus: ultrastructural, immunohistochemical and immunocytochemical characterizations. Tissue Cell 25, 537548.

Héral, M., Deslous-Paoli, J.M., Prou, J., 1986. Dynamiques des productions et des biomasses des huîtres creuses cultivées (Crassostrea angulata et Crassostrea gigas) dans le bassin de Marennes-Oléron depuis un siècle. ICES, C.M. F: 41.

Heude-Berthelin, C., 2000. Etude du métabolisme du glycogène chez l’huître creuse Crassostrea gigas. Impact sur la reproduction et les mortalités estivales. Thèse de l’Université de Caen, 156 pp.

Ibarrola, I., Iglesias, J.I.P., Navarro, E., 1996. Differential absorption of biochemical components in the diet of the cockle Cerastoderma edule: enzymatic responses to variations in seston composition. Can J Zool 74, 1887-1897.

Ibarrola, I., Navarro, E., Iglesias, J.I.P., 1998a. Short-term adaptation of digestive processes in the cockle Cerastoderma edule exposed to different food quantity and quality. J Comp Physiol 168B, 32-40. 
Ibarrola, I., Larretxea, X., Iglesias, J.I.P., Urrutia, M.B., Navarro, E., 1998b. Seasonal variation of digestive enzyme activities in the digestive gland and the crystallin style of the common cockle Cerastoderma edule. Comp Biochem Physiol 121A, 25-34.

Ibarrola, I., Etxeberria, M., Iglesias, J.I.P., Urrutia, M.B., Angulo A., 2000. Acute and acclimated responses of the cockle Cerastoderma edule (L.) to changes in food quality and quantity. II. Enzymatic, cellular and tissular responses of the digestive gland. J Exp Mar Biol Ecol 252, 199-219.

Koyama, I., Komine, S., Hokari, S., Yakushijn, M., Matsunaga, T., Komoda, T., 2001. Expression of alpha-amylase gene in rat liver: liver-specific amylase has a high affinity to glycogen. Electrophoresis 22, 12-17.

Le Moine, S., Sellos, D., Moal, J., Daniel, J.Y., Serrano, F.S.J., Samain, J.F., Van Wormhoudt, A., 1997. Amylase in Pecten maximus (Mollusca, bivalves): protein and cDNA characterization, quantification of the expression in the digestive gland. Mol Mar Biol Biotech 6, 228-237.

Le Moullac, G., Klein, B., Sellos, D., Van Wormhoudt, A., 1997. Adaptation of trypsin, chymotrypsin and alpha-amylase to casein level and protein source in Penaus vannamei (Crustacea Decapoda). J Exp Mar Biol Ecol 208, 107-125.

Logsdon, C.D., Perot, K.J., McDonald, A.R., 1987. Mechanism of glucocorticoid-induced increase in pancreatic amylase gene transcription. J Biol Chem 262, 15765-15769.

Lowry, O.H., Rosebrough, N.J., Farr, A.L., Randall, R.J., 1951. Protein measurement with the Folin phenol reagent. J Biol Chem 193, 251.

Maniatis, T., Goodbourn, S., Fischer, J.A., 1987. Regulation of inductible and tissue-specific gene expression. Science 236, 1237-1245.

Matsui, M., Kakut, M., Misaki, A., 1996. Fine structural features of oyster glycogen: mode of multiple branching. Carbohydrate-polymers 31, 227-235. 
Moal, J., Martin-Jezequel, V., Harris, R.P., Samain, J.F., Poulet, S.A., 1987. Interspecific and intraspecific variability of the chemical composition of marine phytoplancton. Oceanologica Acta 10, 339-346.

Moal, J., Daniel, J.Y., Sellos, D., Van Wormhoudt, A., Samain, J.F., 2000. Amylase mRNA expression in Crassostrea gigas during feeding cycles. J Comp Physiol 170B, 21-26.

Morton, B., 1983. Feeding and Digestion in Bivalvia. In: The Mollusca, Vol. 5 Physiology, Part 2, pp 65-147.

O’Connell, J., Goode, T., Shanahan, F., 1999. PCR in bio-analysis. In: Methods in Molecular Biology, Meltzer, SJ (ed.). Totowa, NJ: Humana Press Inc., 183-193.

Raeymakers, L., 1999. Clinical applications of PCR. In: Methods in Molecular Medecine, Lo, YMD (ed.). Totowa, NJ: Humana Press Inc., 27-38.

Samain, J.F., Daniel, J.Y., Le Coz, J.R., 1977. Trypsine, amylase et protéines du zooplancton: dosage automatique et manuel. J Exp Mar Biol Ecol 29, 279-289.

Samain, J.F., Salaun, M., Diouris, M., Daniel, J.Y., Le Coz, J.R., Moal, J., 1991. Digestive enzymes during development of Pecten maximus, relations with ingestion and absorption processes. 13th. International Congress of E.S.C.P.B.: Research for aquaculture, fundamentals and applied aspects. Antibes-Juan Les Pins. 6-10 Octobre 1991.

Schibler, U., Sierra, F., 1987. Alternative promoters in developmental gene expression. Annual Review of Genetics 21, 237-257.

Schibler, U., Hagenbuchle, O., Wellauer, P.K., Pittet, A.C., 1983. Two promoters of different strengths control the transcription of the mouse alpha-amylase gene Amy-1a in the parotid gland and the liver. Cell 33 (2), 501-508.

Sellos, D., Moal, J., Degremont, L., Huvet, A., Daniel, J.Y., Nicoulaud, S., Boudry, P., Van Wormhoudt, A., Samain, J.F., 2003. Structure of the amylase genes in populations of the 
Pacific cupped oyster Crassostrea gigas: tissue expression and allelic polymorphism. Mar Biotech, in press.

Shaw, P., Sordat, B., Schibler, U., 1985. The two promoters of the mouse alpha-amylase gene Amy-1a are differentially activated during parotid gland differentiation. Cell 40 (4), 907912.

Svensson, B., 1988. Regional distant sequence homology between amylase, $\alpha$-glucosidases and transglucanosylases. FEBS Letters 230, 72-76.

Swanson, K.C., Matthews, J.C., Matthews, A.D., Howell, J.A., Richards, C.J., Harmon, D.L., 2000. Dietary carbohydrate source and energy intake influence the expression of pancreatic alpha-amylase in lambs. J Nut 1, 2157-2165.

Wicker, C., Puigserver, A., Scheele, G., 1984. Dietary regulation of levels of actine mRNA coding for amylase and serine protease zymogens in the rat pancreas. European $\mathrm{J}$ Biochem 139, 381-387. 
Table 1. Expression of both amylase genes and specific amylase activity in five oyster tissues.

\begin{tabular}{rccccccc}
\hline & Digestive gland & Labial palps & Muscle & Mantle & Gills & F \\
\hline A/Act & 0.246 (A) & 0.012 (B) & 0.00007 (B) & 0.0003 (B) & 0.00008 (B) & 358.1 & $<0.001 * * *$ \\
B/Act & 0.0032 (A) & 0.0003 (B) & 0.0001 (B) & 0.0004 (B) & $0.0001(\mathrm{~B})$ & 44.4 & $<0.001 * * *$ \\
Activity & 0.426 (A) & 0.060 (B) & 0.033 (BC) & 0.019 (BC) & 0.003 (C) & 201.7 & $<0.001 * * *$ \\
\hline
\end{tabular}

Amount of amylase transcripts were relative to actin transcripts (A/Act and B/Act). Specific amylase activity was given in UI/mg protein.

Analysis of variance were performed under the general model procedure using SYSTAT 9.0. Test and probability values were both given (F and $P$, respectively). Multiple comparisons were made using the least significant difference (LSD) pairwise multiple comparison test leading to homogenous groups (given between brackets with alphabetic letters). *** Significant at the $P<0.001$ level. 
Table 2. Statistical comparison of A and B amylase transcripts relative to actin transcripts (A/Act, B/Act) in the tissue and food experiments.

\begin{tabular}{cccccccc}
\hline & $\begin{array}{c}\text { Digestive } \\
\text { gland }\end{array}$ & Labial palps & Muscle & Mantle & Gills & $\begin{array}{c}\text { Digestive gland } \\
\text { Low food level }\end{array}$ & $\begin{array}{c}\text { Digestive gland } \\
\text { High food level }\end{array}$ \\
\hline F & 353.1 & 4.88 & 1.24 & 0.45 & 0.22 & 344.1 & 356.7 \\
& & & & & & & \\
$P$ & $<0.001 * * *$ & $0.03 *$ & 0.27 & 0.51 & 0.64 & $<0.001 * * *$ & $<0.001 * * *$
\end{tabular}

Analysis of variance was performed under the general model procedure using SYSTAT 9.0, test and probability values were both given (F and $P$, respectively). * Significant at the $P<0.05$ level; *** significant at the $P<0.001$ level. 
Table 3. Effects of food level on the digestive gland.

\begin{tabular}{ccccc}
\hline & Low food level & High food level & F & $P$ \\
\hline A/Act & 0.245 & 0.288 & 4.43 & $0.038^{*}$ \\
B/Act & 0.0044 & 0.0049 & 0.69 & 0.41 \\
FW & 0.389 & 0.608 & 62.8 & $<0.001 * * *$ \\
Activity & 0.36 & 0.54 & 31.46 & $<0.001 * * *$
\end{tabular}

Effects were measured in terms of the quantity of amylase transcripts relative to actin transcripts (A/Act and B/Act), mean fresh weight (FW, given in grams) and specific amylase activity (given in UI/mg protein). Analysis of variance was performed under the general model procedure using SYSTAT 9.0, test and probability values were both given (F and $P$, respectively). * Significant at the $P<0.05$ level; *** significant at the $P<0.001$ level. 


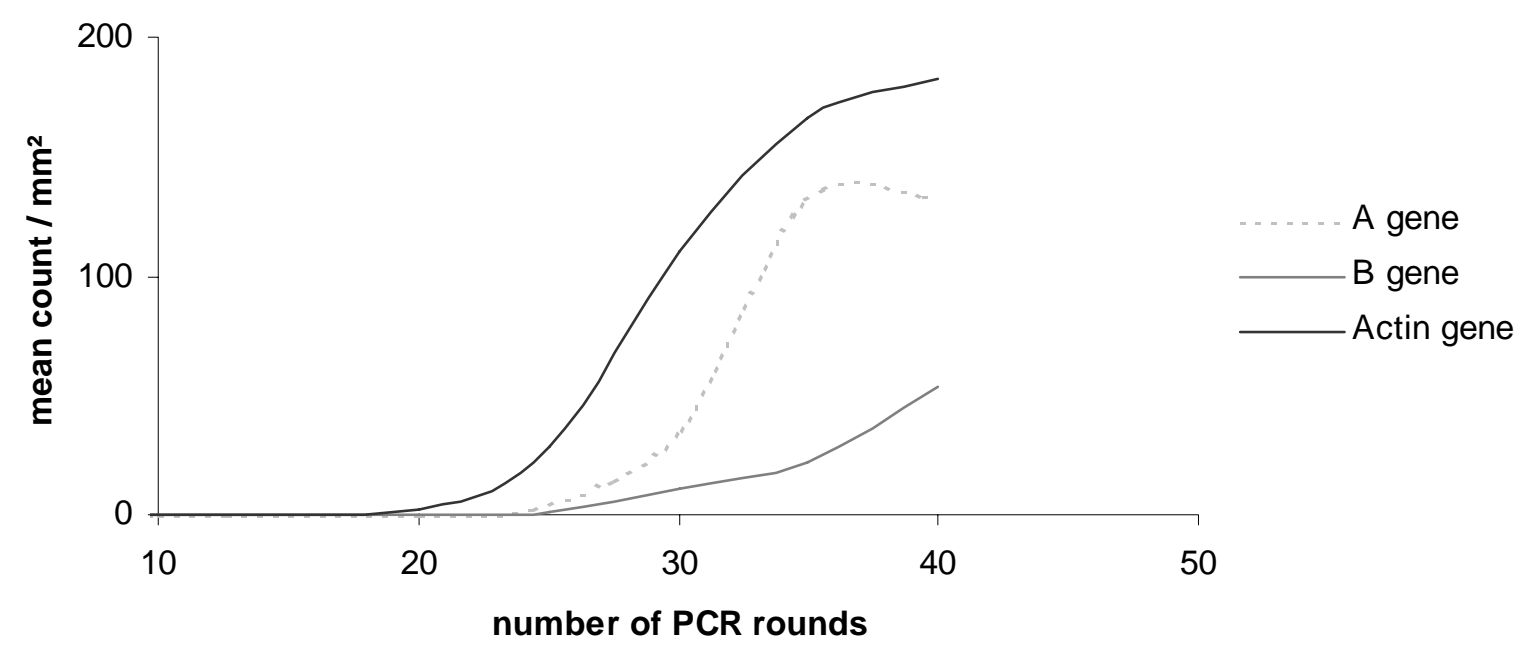

Figure 1. RT-PCR assay of amylase (gene A and B) and actin gene expression in the digestive gland of four T0 samples according to the number of PCR rounds.

PCR were initiated with $3 \mu \mathrm{l}$ of cDNA template from RT products diluted 1/1, 1/20 and 1/40 for amylase B, A and actin genes, respectively. After electrophoresis in 1\% agarose gel, the amount of PCR product was quantified using Multi-analyst software (Biorad, CA) with the background signal removed. The obtained value depended on spot intensity expressed as mean count per pixel and multiplied by spot surface area. 


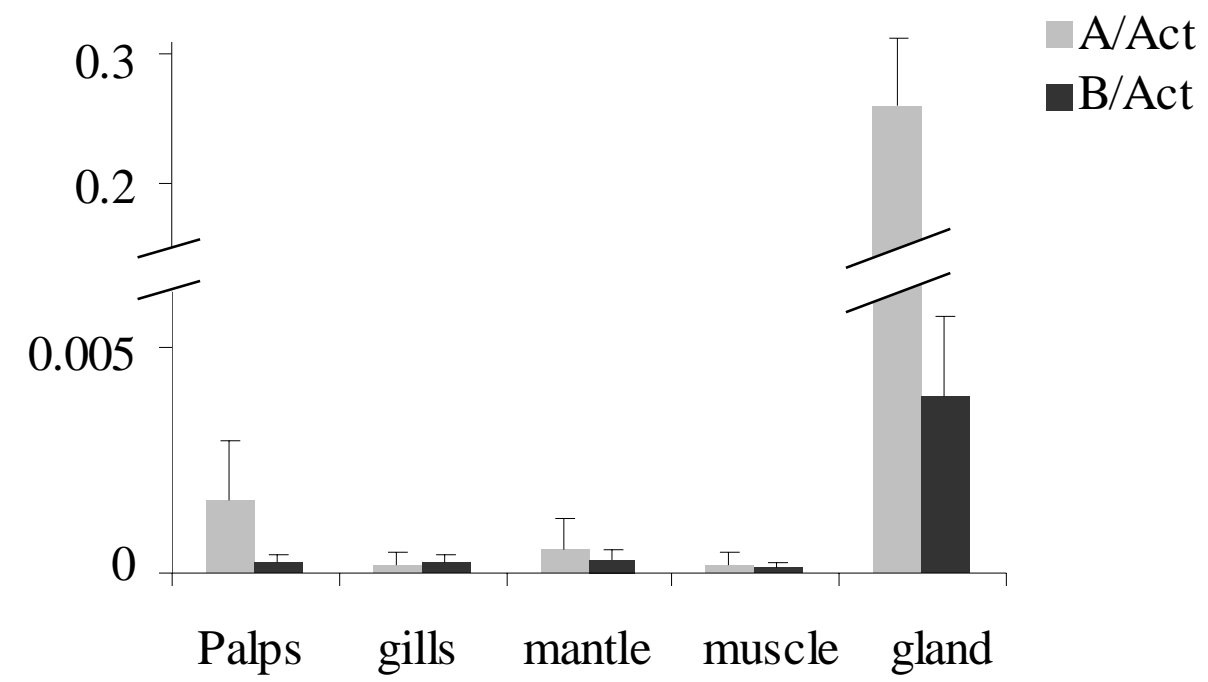

Figure 2. Amount of amylase transcripts relative to actin transcripts (A/Act and B/Act) in five oyster tissues.

Values represented mean of 30 oysters sampled from the Marennes-Oléron Bay (France). 